\title{
Usefulness of the metabolic syndrome diagnosis in obese children in clinical practice
}

\author{
Przydatność rozpoznawania zespołu metabolicznego u otyłych dzieci w praktyce klinicznej
}

\author{
${ }^{1}$ Anna Springwald, ${ }^{2}$ Patrycja Różana-Kowalska, ${ }^{2}$ Piotr Gibała, 'Olimpia Zajdel-Cwynar, \\ ${ }^{1}$ Ewa Małecka-Tendera, 'Paweł Matusik
}

\author{
${ }^{1}$ School of Medicine in Katowice, Department of Pediatrics and Pediatric Endocrinology, Medical University \\ of Silesia, Katowice, Poland \\ ${ }^{2}$ Scientific Society for Medical Students, Medical University of Silesia, Katowice, Poland
}

\begin{abstract}
Introduction: In the light of recent studies, the usefulness of the metabolic syndrome diagnosis in obese pediatric patients seems to be controversial. It leads to the pressing questions, if the metabolic syndrome diagnosis is reflecting risk of the cardiovascular complications in obese children.

Aim of the study: To evaluate the incidence of metabolic syndrome in obese children, asses the role of insulin resistance in the metabolic complications and investigate if the diagnosis of MS has a clinical value in that group of patients.

Material and methods: After the retrospective analysis of 588 records of obese children treated in metabolic outpatient clinic, 289 children (145 boys) in the mean age of 11 years, was qualified to the study. Diagnosis of metabolic syndrome was based on IDF 2009 criteria and HOMA-IR was used in the assessment of insulin resistance.

Results: Metabolic syndrome was diagnosed in 69 children (24\%) including 42 girls (61\%, $p<0.05)$. Mean age was higher (12.4 vs. 10.9, $p<0.05)$ in patients with metabolic syndrome. Initial BMI Z-score was similar in the both groups (2.93 SD vs. 2.92 SD). However, further follow-up showed significantly $(p<0.001)$ less effective BMI z-score reduction in patients with metabolic syndrome. Insulin resistance was observed significantly more often in children with metabolic syndrome (77\% vs. 35\%, $p<0.0001)$. Moreover, aminotransferases were significantly higher in boys with metabolic syndrome (AST = $35 \mathrm{vs.} 28 \mathrm{U} / \mathrm{l}, \mathrm{ALT}=38 \mathrm{vs} .23 \mathrm{U} / \mathrm{l}, p<0.0001$ ). Conclusions: The diagnosis of metabolic syndrome in obese children seems to have a predictive value for the clinical practice. Affected children are older and their criteria are present more often in girls. Insulin resistance seems to be an important factor associated with metabolic syndrome in obese children. The outcomes of behavioral therapy are less effective in children with metabolic syndrome. Affected boys are at higher risk of non-alcoholic fatty liver disease (NAFLD) in the future.
\end{abstract}

Key words:

childhood obesity, metabolic syndrome, insulin resistance.

\section{Streszczenie}

Wstęp: Przydatność kliniczna rozpoznawania zespołu metabolicznego (ZM) u otyłych dzieci w świetle ostatnich badań jest kontrowersyjna. Pojawia się pytanie, czy rozpoznanie ZM odzwierciedla ryzyko występowania powikłań otyłości u dzieci.

Cel pracy: Ocena występowania ZM u otyłych dzieci, ewaluacja roli insulinooporności w powikłaniach metabolicznych oraz zbadanie, czy diagnozowanie ZM jest użyteczne dla codziennej praktyki klinicznej.

Materiał i metody: Analizie retrospektywnej poddano 588 otyłych dzieci leczonych w poradni metabolicznej, 289 dzieci (145 chłopców) w wieku średnio 11 lat zakwalifikowano do badania. Zespół metaboliczny rozpoznawano na podstawie kryteriów IDF 2009. Do określenia insulinooporności użyto wskaźnika HOMA-IR.

Wyniki: Zespół metaboliczny rozpoznano u 69 dzieci (24\%), w tym u 42 dziewczynek (61\%, p < 0,05). Średni wiek dzieci był wyższy $(12,4$ vs 10,9; $p<0,05)$ u pacjentów z zespołem metabolicznym. Początkowa wartość BMI Z-score nie różniła się znamiennie w obu grupach (2,93 SD vs 2,92 SD). Dalsza obserwacja wykazała znamiennie mniejszą $(p<0,001)$ redukcję BMI Z-score u pacjentów z ZM. Insulinooporność obserwowano znamiennie częściej u dzieci z ZM (77\% vs 35\%; $p<0,0001)$. Natomiast stężenia aminotransferaz były znamiennie większe u chłopców z ZM (AST = 35 vs $28 \mathrm{U} / \mathrm{l}$; ALT = 38 vs $23 \mathrm{U} / \mathrm{l}, p<0,0001)$. 
Wnioski: Diagnozowanie zespołu metabolicznego u otyłych dzieci wydaje się mieć istotne znaczenie w praktyce klinicznej. Zespół ten występuje częściej u dziewczynek i u dzieci starszych. Insulinooporność jest ważnym czynnikiem skojarzonym z ZM u otyłych dzieci. Terapia zachowawcza otyłości jest mniej efektywna u pacjentów z ZM. Chłopcy dotknięci tym zespołem wydają się bardziej narażeni na wystąpienie niealkoholowej stłuszczeniowej choroby wątroby (NAFLD) w przyszłości.

\section{Słowa kluczowe:}

otyłość dziecięca, zespół metaboliczny, insulinooporność.

\section{Introduction}

Metabolic syndrome is an accumulation of several disorders, which includes visceral obesity, elevated fasting glucose, triglycerides, blood pressure values and reduced high-density lipoprotein cholesterol. The underlying etiology is insulin resistance caused by extra weight, obesity, lack of physical activity and genetic predisposition [1]. Metabolic syndrome it is not the disease, but the group of risk factors which poses a great danger of developing atherosclerotic cardiovascular disease, insulin resistance, diabetes mellitus and vascular and neurological complications such as a cerebrovascular accident in the future.

Until recently metabolic syndrome has been considered as a problem of adulthood only. In view of the increasing obesity in children and adolescents, which becomes the epidemic in most countries, the components of this syndrome like dyslipidemia, hypertension and impaired glucose tolerance are now described commonly in the young age [2]. However its description in the pediatric literature is still limited.

While the criteria of metabolic syndrome in adults are well known and unified worldwide, we lack of the standardized definition and criteria which should be used for the diagnosis of MS among children and adolescents. The main problem poses the fact that, we should use the norms not only in the terms of the gender but also of the age and race identity. The organism of the child is developing very fast and the values of the various parameters are different at the different stages of the development. Creating the centile charts for these parameters is necessary. The are some proposals for the criteria of metabolic syndrome in children. The most useful criteria seem to be the one presented by Ferranti et al., Cook et al. and IDF consensus criteria [3-5].

According to the recent studies the prevalence of MS in the group of children in different countries has been confirmed in $3-4 \%$ [6]. Among adolescents in USA has been reported to be $4,2 \%$ and among obese adolescents (BMI > 95 pc) 28,7\% [4]. In Europe the situation seems to be better. When only obese children were taken into account MS was presented in $9 \%$ of them in Hungary and in 14\% in Silesia [7]. The results are also different because of different criteria which were taken into consideration.

In the light of recent studies, the usefulness of the metabolic syndrome diagnosis in obese pediatric patients seems to be controversial. It leads to the pressing questions, if the MS diagnosis has the importance in daily clinical practice during the treatment of childhood obesity.

\section{Aim of study}

The aim of this study was to evaluate the incidence of metabolic syndrome (based on the IDF consensus criteria) in obese children and to asses the role of the insulin resistance in the metabolic complications in that group of patients. What is more the influence on the effectiveness of the therapy in obese children was investigated in the terms of the presence of MS as well as independent components of MS including elevated high- density lipoprotein and triglycerides, elevated fasting insulin level and insulin resistance.

\section{Material and methods}

\section{Study population}

From records of 588 obese children treated in metabolic outpatient clinic, 289 children (145 boys) was qualified to the study.

The study group consisted of obese children whose blood tests such as Triglycerides (TG), Total cholesterol (Tch), high density lipoprotein (HDL), fasting glucose, insulin and HOMA $\mathrm{IR}$ were performed at each visit.

Mean age was $10.73 \pm 3.57$. We divided study population on two subgroups: (MS) with metabolic syndrome 69 children including 42 girls (61\%) and the second group without MS 220 children. More than $70 \%$ of children lived in cities over 100,000 of people. The retrospective case-control study was conducted in the Metabolic Outpatient Clinic in Children's Hospital in Katowice between 2014 and 2016. The data come from years 2005 to 2016.

Exclusion criteria comprised secondary causes of obesity such as chronic intake of certain drugs (like steroids, anti-epileptic), endocrinopathies (like Hashimoto thyroiditis), genetically determined disorders and other chronic diseases and lacking of the clinical or biochemical data. As the therapy is concerned, only behavioral treatment was introduced. The therapy included lifestyle modification. Children were encouraged to increased physical activity and change eating patterns. Moreover they were supported by the dietician and psychologist.

\section{Obesity diagnosis}

Obesity was determined according to WHO growth references for children from 2007. We used BMI Z-score for age and sex. Children with Z-score +2SD or more were classified as obese. 


\section{Anthropometric measurement}

Patients visited outpatient clinic every three months. Each time anthropometric measurements like height, weight and body mass index (BMI) were performed. Weight was measured in the standing position with an accuracy of $100 \mathrm{~g}$ Height was obtained in the standing position with a fixed stadiometer with an accuracy of $1 \mathrm{~cm}$. BMI was calculated according to standard formula (kilograms per meter squared). $\mathrm{BMI}$ Z-scores were derived using WHO AnthroPlus, version 1.0.4 (based on World Health Organization growth references).

Moreover measurements occurred results of Triglycerides (TG), Total cholesterol (Tch), heigh density lipoprotein (HDL), glucose, insulin and aminotransferase (AST, ALT) was consistent with guidelines of the Polish Pediatric Society.

\section{Metabolic syndrome criteria}

Diagnosis of metabolic syndrome was based on IDF 2009 criteria and HOMA-IR was used to asses insulin resistance.

\section{Ethic consideration}

The study was retrospective analysis of the history of patients treated in Metabolic Outpatient Clinic. Therefore we did not apply for bioethical committee permission.

\section{Statistics}

Comparative analysis of the groups for the variables with normal distribution was performed using the Shapiro-Wilk test. Analysis for qualitative variables was carried out using a chi square test. Analysis for quantitative variables with normal distribution was carried out using T test. Analysis for quantitative variables without normal distribution was carried out using $U$ Mann-Whitney test. All results were analysed in the Statis- tica $^{\text {TM }} 12 \mathrm{PL}$ software. The criterion of statistical significance was $p<0.05$.

\section{Results}

Metabolic syndrome which was diagnosed by the IDF criteria had 69 children (24\%). Almost $61 \%$ of children who had metabolic syndrome were girls.

Children with metabolic syndrome were statistically significant older than patients without MS respectively (1.4 vs. 10.9 SD, $p=0.03$ ).

The initial BMI Z-score was close both in the group with metabolic syndrome and without it (3.00 SD vs. 2.92 SD, $p>0.05$ ). But further follow-up showed less effective BMI z-score reduction in children with metabolic syndrome (Fig. 1). Moreover the initial BMI was significant higher in group of children with metabolic syndrome (29.39 vs. 26.48 SD 5.88, $p=0.0006$ )

Insulin resistance measured by HOMAiR was observed significantly more often in children with metabolic syndrome $(77 \%$ vs. $35 \%, p=0.0001)$. In addition insulin resistance was more frequent in both groups boys and girls with metabolic syndrome respectively ( $70 \%$ vs. $30 \%, p=0.0001 ; 66 \%$ vs. $33 \%, p=0.0001$ )

Aminotransferases were significantly elevated in boys with metabolic syndrome (AST $=35$ vs. $28 \mathrm{U} / \mathrm{l}, \mathrm{ALT}=38 \mathrm{vs} .23 \mathrm{U} / \mathrm{l}$, $p=0.0001$ ). But on the other hand we did not observed any differences in group of girls.

There were no significantly differences between delta BMI and value of triglycerides, HDL and HOMAiR on each visit (Fig. 2). We did observed differences between BMI Z-score and value of fasting insulin on each visit. Children who have lower value of fasting insulin were reducing BMI Z-score better than those who have high value of fasting insulin (Fig. 3).

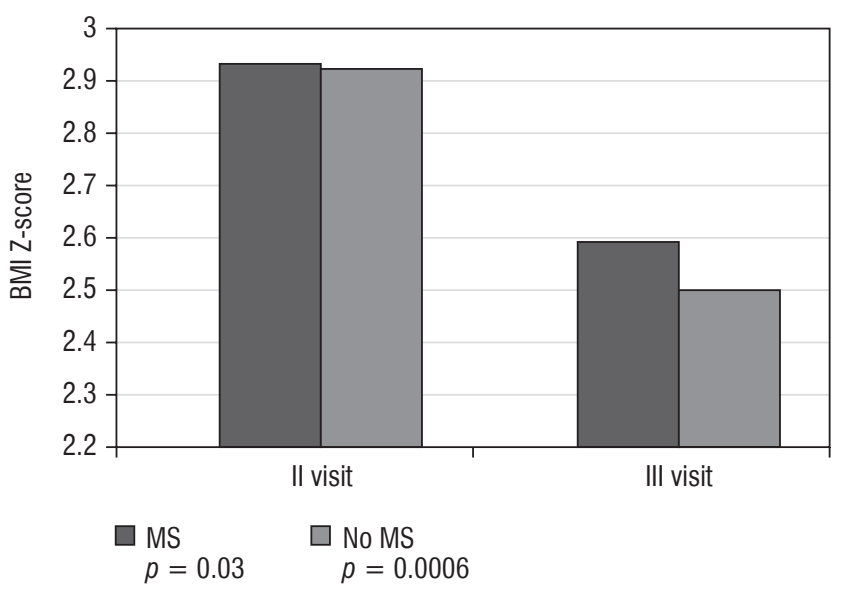

Figure 1. Reduction of BMI Z-score in children with MS and without MS on following visit $p<0.05$

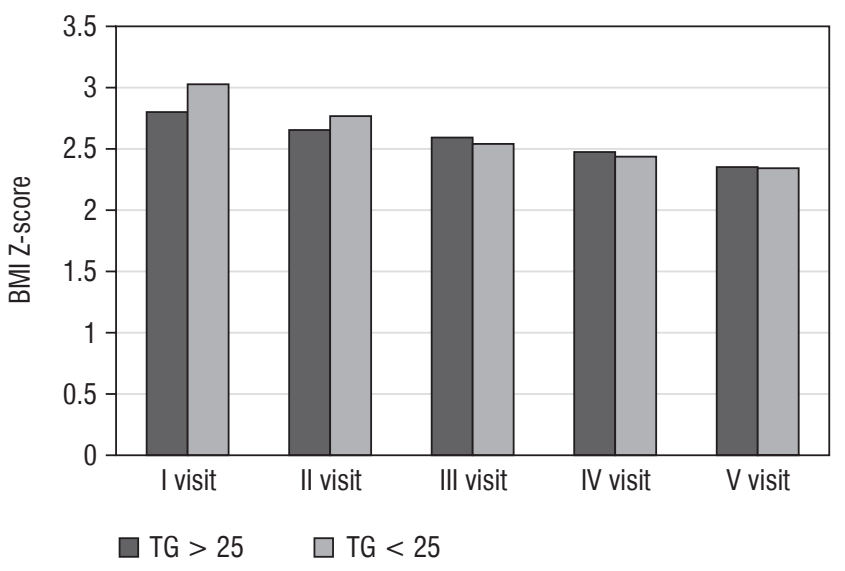

Figure 2. Reduction of BMI Z-score in children with TG $>150$ and $T G<150$ on following visit $p>0.05$ 


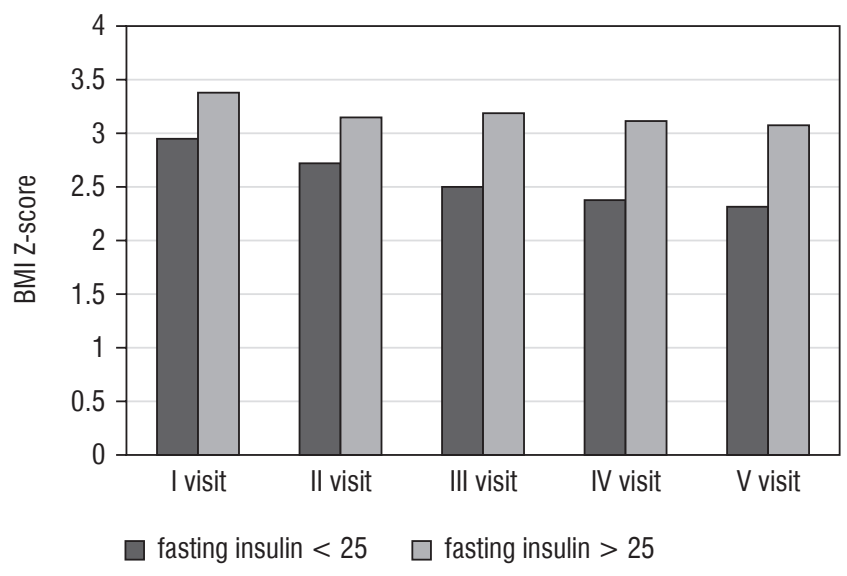

Figure 3. Reduction of BMI Z-score in children with Fasting insulin $<25$ and Fasting insulin $>25$ on following visit $p<0.05$.

\section{Discussion}

There is no doubt that obese children had significantly higher metabolic syndrome prevalence compared with their counterparts with normal weight [4, 8, 9]. In the systematic review Friend et al. Showed that the median prevalence of MS in children generally was $3.3 \%$, while in overweight population was $11,9 \%$ and in children with obesity was $29.25 \%$ [9].

In our study MS was diagnosed in $24 \%$ of obese patients. Similar results were obtained by Cook et al., while the MS was reported in $28,7 \%$ of obese adolescents in USA. Alarming data come from Turkey. Özlem et al. compared the incidence of MS in turkish obese children and adolescents by using three different definitions, according to the modified $\mathrm{WHO}$, Cook and the International Diabetes Federation consensus criteria. Respectively MS was confirmed in 39\%, 34\% and 33\% of those patients [10]. In the European studies the numbers are lower. In the study conducted by Bokor et al. In the group of obese children from France, Greece, Italy, Poland and Hungary,12.2\% of them had MS [11]. Another work comes from Spain. Guijarro de Armas et al. reported that 19,6\% children with severe obesity had MS, according to IDF criteria, 2007 [12]. Similar results were presented in the study of Rizzo et al. Adolescents from Brasil with overweight, obesity and extreme obesity were enrolled into this research. By around $18 \%$ of them MS was confirmed [13]. For now in China the situation is better. Only in $6,6 \%$ of obese children MS was diagnosed. However the prevalence of obesity and MS is on the increase because of undergoing transition to Western lifestyle [8]. Our research showed that MS is diagnosed more often in Silesia than in children from other parts of Poland and Europe. Our results were more similar to the findings from USA, which is an alarming report. It may resultt from the fact that Silesia is relatively well-to-do region with the greatest urban area in Poland. The welfare and
Western lifestyle and dietary patterns may cause this situation. Some of studies confirm the fact that the prevalence of obesity is higher among city residents than among township and rural area residents [14]. By contrast other works reported higher prevalence in obesity in rural areas [15]. Another reason for such a big amount of children with MS in the area of our study may be the fact that only patients with severe problems related to obesity wanted to take a treatment in our outpatients clinic.

It is still a remaining question if the gender plays a role in the prevalence of MS. In our research we observed incidence of MS more often in the group of obese girls (61\%). Similar phenomenon was observed in the trial of Rizzo et al., where the risk factors for MS were more prevalent in females [13]. A large amount of studies reported higher prevalence of insulin resistance in the group of girls $[13,16]$. On the other hand the some studies, for example Friend et al. and Cook et al. revealed higher median MS prevalence in boys compared to girls $(5.1 \%$ vs. $3.0 \%$; $6.1 \%$ vs. $2.1 \%$ ) [4, 9]. However in the large amount of studies no significant differences by sex were found $[17,18]$.

As we found in our study, the mean age of obese children with MS was significantly higher compared to the age of those one without this disorder (12.4 vs. 10.9). This trend is described commonly by numerous authors $[9,10,17]$. MS prevalence is higher in older patients, especially who are undergoing puberty. It was confirmed by a large amount of studies. According to Tanner, in stage of II-IV insulin sensitivity of peripheral tissues decreases by around 30\% [2, 19]. The level of fasting insulin and glucose is elevated. The main reason seems to be the changes in releasing of hormones, like growth hormone and consequently insulin-like growth factor 1 and 2, which contribute to insulin resistance [2].

As we observed in our investigation, the initial BMI Z-score was close both in the group of children with and without MS (2.93 SD vs. 2.92 SD). Nevertheless further follow-up showed less effective BMI z-score reduction in children with metabolic syndrome (2.59 SD vs. $2.50 \mathrm{SD}$ ) and with elevated fasting insulin. It demonstrates that the behavioral therapy of obese children with metabolic complications is less effective and in these cases the weight loss is significantly reduced. However the level of triglycerides, HDL and insulin resistance (the value of HOMA-IR) separately, did not have an impact on the effectiveness of the therapy. There were no significant differences in delta BMI Z-score in patients with or without these metabolic disorder independently. We did not found other studies investigating these correlations. More surveys are required.

Our study confirmed that insulin resistance is observed significantly more often in children with MS (77\% vs. 35\%). The findings in other studies are in agreement with this correlation $[12,13,17]$. The study of Guijarro et al. showed that in children who met 3 or more criteria of MS insulin resistance was significantly greater than in patients with 1 or 2 MS criteria [12]. Insulin resistance is the principal metabolic abnormality that is common to the development of the metabolic syndrome in both children and adults [20]. It is strictly related to the evolution of hypertension, dyslipidemia, impaired glucose tolerance, hepatic steatosis, which are the components of MS. According 
to the third National Health and Nutrition Examination survey, insulin resistance is present in approximately $24 \%$ of adults in the USA and is strongly correlated with coronary heart disease, stroke, type 2 diabetes, and all-cause mortality. It has been clearly shown that IRS origins extend back to the childhood and progress in their pubertal transition into adulthood. Our population is facing the risk that children will be less healthy and die younger than their parents $[21,22]$.

We observed in our investigation significant elevation of aminotransferases in the group of boys with MS (AST: 35 vs. $28 \mathrm{U} / \mathrm{l}$, ALT: 38 vs. $23 \mathrm{U} / \mathrm{l})$. Similar results were obtained by Schwimmer et al., while abnormal ALT was significantly more prevalent in boys (44\%) than in girls (7\%) [23]. Seo et al. also confirmed that boys had liver enzymes elevated more frequently than girls $(7.0 \%$ vs. $3.1 \%)$. What is more boys had higher metabolic co-morbidities such as hypertension and hyperglycemia [18]. Boys have been identified as sex in which the steatohepatitis is more commonly developed in the analysis of studies that has been released since 1998 on NAFLD [24]. The ratio of boys to girls was $2: 1$ [25]. These differences could be related to the levels of circulating sex hormones (estrogen-testosterone ratio), hepatic expression of sex hormone receptors and pattern of growth hormone secretion. In fact, it has been shown that estrogens act as anti-apoptotic, anti-fibrogenic, and anti-inflammatory agents [26]. On the other hand in the trial of Quirós-Tejeira et al. the percentage of overweight children with elevated ALT did not differ by sex, age, or Tanner stage [27]. Among the authors Bălănescu et al. patients with MS had a higher risk for NAFLD. But in comparison to our study NAFLD was diagnosed more often in girls. Patients under the age of

\section{References}

1. Reaven GM. Banting lecture 1988. Role of insulin resistance in human disease. Diabetes 1988; 37: 1595-1607.

2. Zachurzok-Buczyńska A, Małecka-Tendera E. Zespół metaboliczny u dzieci i młodzieży. Endokrynologia, Otyłość i Zaburzenia Przemiany Materii 2005, 1: 13-20.

3. Ferranti A, Gauvreau K, Ludwig D, et al. Prevalence of metabolic syndrome in American adolescents. Findings from the third National Health and Nutrition Examination Survey. Circulation 2004; 110: 2494-2497. doi: 10.1161/01.CIR.0000145117.40114.C7

4. Cook S, Weitzman M, Auinger P, et al. Prevalence of a metabolic syndrome phenotype in adolescents: findings from the third $\mathrm{Na}$ tional Health and Nutrition Examination Survey, 1988-1994. Arch Pediatr Adolesc Med 2003; 157: 821-827. doi: 10.1001/archpedi.157.8.821

5. Zimmet P, Alberti KG, Kaufman F, et al. IDF Consensus Group. The metabolic syndrome in children and adolescents - an IDF consensus report. Pediatr Diabetes 2007; 8: 299-306. doi: 10.1111/j.13995448.2007.00271.x

6. Chen W, Bao W, Begum S, et al. Age-related patterns of the clustering of cardiovascular risk variables of syndrome $X$ from childhood ten with both MS and NAFLD met the triglyceride criterion more frequently. This study showed that triglyceride levels are associated with NAFLD independently [28].These would be beneficial in order to detect possible NAFLD or MS at younger age and even if IDF Consensus Criteria are still not yet met, a close follow-up of these patients is mandatory. Bjorklund et al. showed the association between the development of NAFLD and the occurrence of MS. Children having liver steatosis and elevated liver enzymes are most often asymptomatic [29]. That is why the screening test for NAFLD development among obese children is so important. Untreated steatohepatitis can lead to cirrhosis and liver transplant [24]. Nanda et al. pointed out that slow, consistent weight loss has been shown to be effective in childhood NAFLD, based on improvement of serum aminotransferases or liver sonogram [30]

\section{Conclusions}

Our study confirmed that the diagnosis of metabolic syndrome in obese children seems to have a predictive value for the clinical practice. Early intervention to control childhood obesity is essential to prevent cardiovascular morbidity and mortality in the future. A timely identifying the risk factors and diagnosis of MS, appropriate prevention and treatment of obesity and insulin resistance are necessary to reduce the risk of chronic diseases later in life.

Greater efforts are required to avoid the further increase in obesity and its metabolic and cardiovascular complications in our future societies. to young adulthood in a population made up of black and white subjects: the Bogalusa Heart Study. Diabetes 2000; 49: 1042-1048.

7. Csabi S, Torok K, Jeges S, et al. Presence of metabolic cardiovascular syndrome in obese children. Eur J Pediatr 2000; 159: 91-94.

8. Haiquan X, Yanping L, Ailing L, et al. Prevalence of the metabolic syndrome among children from six cities of China. BMC Public Health 2012; 12: 13. doi: 10.1186/1471-2458-12-13

9. Friend A, Craig L, Turner S, et al. The prevalence of metabolic syndrome in children: a systematic review of the literature. Metab Syndr Relat Disord 2013; 11: 71-80. doi: 10.1089/met.2012.0122

10. Sangun Ö, Dündar B, Köşker M, et al. Prevalence of Metabolic Syndrome in Obese Children and Adolescents using Three Different Criteria and Evaluation of Risk Factors. J Clin Res Pediatr Endocrinol 2011; 3: 70-76. doi: 10.4274/jcrpe.v3i2.15

11. Bokor S, Frelut ML, Vania A, et al. Prevalence of metabolic syndrome in European obese children. Int $\mathrm{J}$ Pediatr Obes 2008; 3 Suppl 2: 3-8. doi: 10.1080/17477160802404509

12. Guijarro de Armas MA, Monereo Megías S, Merino Viveros M, et al. Prevalence of metabolic syndrome in a population of obese children and adolescents. Endocrinol Nutr 2012; 59: 155-159. doi: 10.1016/j.endonu.2012.01.003 
13. Rizzo AC, Goldberg TB, Silva CC, et al. Metabolic syndrome risk factors in overweight, obese, and extremely obese Brazilian adolescents. Nutr J 2013; 12: 19. doi: 10.1186/1475-2891-12-19

14. Zou Y, Zhang R, Zhou B, et al. A comparison study on the prevalence of obesity and its associated factors among city, township and rural area adults in China. BMJ Open 2015; 5: e008417. doi: 10.1136/bmjopen-2015-008417

15. Befort CA, Nazir N, Perri MG. Prevalence of obesity among adults from rural and urban areas of the United States: findings from NHANES (2005-2008). Rural Health 2012 Fall; 28: 392-397. doi: 10.1111/j.1748-0361.2012.00411.x

16. Moran A, Jacobs DJ, Steinberger J, et al. Changes in Insulin Resistance and Cardiovascular Risk During Adolescence: Establishment of Differential Risk in Males and Females. Circulation 2008, 117: 2361-2368. doi: 10.1161/CIRCULATIONAHA.107.704569.

17. Tapia Ceballos L, López Siguero JP, Jurado Ortiz A. Prevalence of metabolic syndrome and its components in obese children and adolescents. An Pediatr (Barc) 2007; 67: 352-361.

18. Seo JY, Kim JH. Validation of surrogate markers for metabolic syndrome and cardiometabolic risk factor clustering in children and adolescents: A nationwide population-based study. PLoS One 2017; 12: e0186050. doi: 10.1371/journal.pone.0186050

19. Hadjiyannakis $S$. The metabolic syndrome in children and adolescents. Paediatr Child Health 2005; 10: 41-47.

20. Nelson RA, Bremer AA. Insulin resistance and metabolic syndrome in the pediatric population. Metab Syndr Relat Disord 2010; 8: 1-14. doi: 10.1089/met.2009.0068

21. Rosenberg B, Moran A, Sinaiko AR. Insulin resistance (metabolic) syndrome in children. Panminerva Med 2005; 47: 229-244.
22. Maclaren NK, Gujral S, Ten S, et al. Childhood obesity and insulin resistance. Cell Biochem Biophys 2007; 48: 73-78.

23. Schwimmer JB, McGreal N, Deutsch R, et al. Influence of gender, race, and ethnicity on suspected fatty liver in obese adolescents. Pediatrics 2005; 115: e561-5. doi: 10.1542/peds.2004-1832

24. Manti S, Romano C, Chirico V, et al. Nonalcoholic Fatty liver disease/non-alcoholic steatohepatitis in childhood: endocrine-metabolic "mal-programming". Hepat Mon 2014; 14: e17641. doi: 10.5812/hepatmon.17641

25. Giorgio V, Prono F, Graziano F, et al. Pediatric non alcoholic fatty liver disease: old and new concepts on development, progression, metabolic insight and potential treatment targets. BMC Pediatr 2013; 13: 40. doi: 10.1186/1471-2431-13-40

26. Lonardo A, Carani C, Carulli N, et al. 'Endocrine NAFLD' a hormonocentric perspective of nonalcoholic fatty liver disease pathogenesis. J Hepatol 2006; 44: 1196-1207. doi: 10.1016/j.jhep.2006.03.005

27. Quiros-Tejeira RE, Rivera CA, Ziba TT, et al. Risk for nonalcoholic fatty liver disease in Hispanic youth with BMI > or = 95th percentile. J Pediatr Gastroenterol Nutr 2007; 44: 228-236. doi: 10.1097/ MPG.0b013e31802d4acc

28. Bălănescu A, Bălănescu P, Comănici V, et al. Lipid profile pattern in pediatric overweight population with or without NAFLD in relation to IDF criteria for metabolic syndrome: a preliminary study. Rom J Intern Med 2018; 56: 47-54. doi: 10.1515/rjim-2017-0040

29. Björklund J, Laursen T, Kazankov K, et al. Non-alcoholic fatty liver disease in children and adolescents. Ugeskr Laeger 2017; 179: pii: V11160796

30. Nanda K. Non-alcoholic steatohepatitis in children. Pediatr Transplant 2004; 8: 613-618. doi: 10.1111/j.1399-3046.2004.00241.x 